\title{
War of the microbial world: Acanthamoeba spp. interactions with microorganisms
}

\author{
Mohammad Ridwane Mungroo $^{1} \cdot$ Ruqaiyyah Siddiqui $^{2} \cdot$ Naveed Ahmed Khan $^{1,3}$
}

Received: 15 December 2020 / Accepted: 9 June 2021 / Published online: 18 June 2021

(c) Institute of Microbiology, Academy of Sciences of the Czech Republic, v.v.i. 2021

\begin{abstract}
Acanthamoeba is known to interact with a plethora of microorganisms such as bacteria, fungi and viruses. In these interactions, the amoebae can be predatory in nature, transmission vehicle or an incubator. Amoebae consume microorganisms, especially bacteria, as food source to fulfil their nutritional needs by taking up bacteria through phagocytosis and lysing them in phagolysosomes and hence play an eminent role in the regulation of bacterial density in the nature and accountable for eradication of around $60 \%$ of the bacterial population in the environment. Acanthamoeba can also act as a "Trojan horse" for microbial transmission in the environment. Additionally, Acanthamoeba may serve as an incubator-like reservoir for microorganisms, including those that are pathogenic to humans, where the microorganisms use amoebae's defences to resist harsh environment and evade host defences and drugs, whilst growing in numbers inside the amoebae. Furthermore, amoebae can also be used as a "genetic melting pot" where exchange of genes as well as adaptation of microorganisms, leading to higher pathogenicity, may arise. Here, we describe bacteria, fungi and viruses that are known to interact with Acanthamoeba spp.
\end{abstract}

\section{Introduction}

Acanthamoeba castellanii is known to interact with bacteria and viruses as well as fungi (Table 1) (Mella et al. 2016; Siddiqui and Khan 2012). The ability of bacteria to infect and lyse Acanthamoeba has been recorded since 1954 , whilst the ability of bacteria to act as an endosymbiont was reported in 1975, and the potential of Acanthamoeba as a reservoir for pathogenic bacteria was suggested in 1978 (Drozanski 1956; Prasad and Gupta 1978; Proca-Ciobanu et al. 1975). Behaviour of the endosymbionts may vary depending on conditions, such as temperature, $\mathrm{pH}$, osmolarity and availability of food (Scheid 2014). It is also known that amoebae can serve as genetic "melting pot", that allows exchange of genes (Moreira and Brochier-Armanet 2008;

Naveed Ahmed Khan

naveed5438@gmail.com

1 Department of Clinical Sciences, College of Medicine, University of Sharjah, Sharjah, United Arab Emirates

2 College of Arts and Sciences, American University of Sharjah, Sharjah, United Arab Emirates

3 Research Institute for Medical and Health Sciences, University of Sharjah, University City, Sharjah, United Arab Emirates
Grillot-Courvalin et al. 1998). Intracellular growth of bacteria in amoebae is suggested to be essential for adaptation of bacteria to higher eukaryotic cells, leading to increased pathogenicity of the bacteria and resistance to destruction by macrophages (Harb et al. 2000; Molmeret et al. 2005; Albert-Weissenberger et al. 2007; Greub and Raoul 2004; Thomas et al. 2006). The community of bacteria associated with amoebae is very large and diverse and can be classified in 155 different taxa (Delafont et al. 2016). Whilst it is known that Acanthamoeba can feed on bacteria, little is known about the mechanisms through which the amoebae locate the bacteria. Comparing it with an amoeba that uses chemotaxis, Dictyostelium, it was revealed that Acanthamoeba do not use chemotaxis as the primary mechanism to find bacterial food sources (Kuburich et al. 2016). Interestingly, in an experiment comparing the ability of ciliates and Acanthamoeba, it was revealed that the competition was asymmetric in favour of the ciliates, but Acanthamoeba had better long-term negative effect, both in the open-water phase as well as in biofilm, on bacterial biomass (Zhang et al. 2014). A large number of bacterial and viral species that have been shown to interact with Acanthamoeba (Balczun and Scheid 2017). Here, we describe some of the interactions of Acanthamoeba with microorganisms (Fig. 1). 
Table 1 Microorganism that interacts with Acanthamoeba. Several bacteria, fungi and viruses that interact with Acanthamoeba as well as changes that occur following the interaction are described

\begin{tabular}{|c|c|c|}
\hline Organism & Changes & References \\
\hline \multicolumn{3}{|l|}{ Bacteria } \\
\hline Amoebophilus asiaticus & Intracellular multiplication & Horn et al. (2001) \\
\hline Arcobacter butzleri & Not described & Medina et al. (2014) \\
\hline Bacillus anthracis & Intracellular multiplication & Dey et al. (2012) \\
\hline Burkholderia cepacia & Intracellular growth & Landers et al. (2000) \\
\hline Burkholderia pickettii & Intracellular multiplication & Michel and Hauröder (1997) \\
\hline Campylobacter jejuni & Increase in bacterial resistance to disinfection & Snelling et al. (2005) \\
\hline Candidatus Paracaedibacter symbiosus & Not described & Horn et al. (1999) \\
\hline Chlamydia pneumoniae & Intracellular growth & Essig et al. (1997) \\
\hline Chlamydiales & Increase in amoebae pathogenicity & Fritsche et al. (1998) \\
\hline Citrobacter freundii & Increase in bacterial resistance to chlorine & King et al. (1988) \\
\hline Coxiella burnetii & Not described & La Scola and Raoult (2001) \\
\hline Cytophaga johnsonae & Intracellular multiplication & Hoffmann and Michel (2001) \\
\hline Enterobacter agglomerans & Increase in bacterial resistance to chlorine & King et al. (1988) \\
\hline Enterobacter cloacae & Increase in bacterial resistance to chlorine & King et al. (1988) \\
\hline Escherichia coli & $\begin{array}{l}\text { Intracellular growth and } \\
\text { increase in bacterial resistance to chlorine and } \\
\text { antibiotics }\end{array}$ & $\begin{array}{l}\text { King et al. (1988) } \\
\text { Barker et al. (1999) }\end{array}$ \\
\hline Flavobacterium indologines & Intracellular multiplication & Hoffmann and Michel (2001) \\
\hline Flavobacterium johnsoniae & Not described & Horn et al. (2001) \\
\hline Flavobacterium succinicans & Not described & Horn et al. (2001) \\
\hline Francisella tularensis & Intracellular growth & Abd et al. (2003) \\
\hline Helicobacter pylori & Intracellular growth & $\begin{array}{l}\text { Winiecka-Krusnell et al. (2002) } \\
\text { Moreno-Mesonero et al. (2016) }\end{array}$ \\
\hline Klebsiella oxytoca & Increase in bacterial resistance to chlorine & King et al. (1988) \\
\hline Klebsiella pneumoniae & Increase in bacterial resistance to chlorine & King et al. (1988) \\
\hline Legionella pneumophila & $\begin{array}{l}\text { Intracellular growth } \\
\text { Increase in invasiveness }\end{array}$ & $\begin{array}{l}\text { Rowbotham (1980) } \\
\text { Cirillo et al. (1994) }\end{array}$ \\
\hline Legionella sp. & Not described & Michel et al. (1997) \\
\hline Listeria monocytogenes & Intracellular multiplication & Ly and Müller (1990) \\
\hline Mobiluncus curtisii & Intracellular multiplication & Tomov et al. (1999) \\
\hline Mycobacterium avium & $\begin{array}{l}\text { Intracellular multiplication, increase in bacterial } \\
\text { virulence }\end{array}$ & Cirillo et al. (1997) \\
\hline Mycobacterium xenopi & Intracellular multiplication & Drancourt et al. (2007) \\
\hline Porphyromonas gingivalis & Intracellular multiplication & Wagner et al. (2006) \\
\hline Prevotella intermedia & Intracellular multiplication & Wagner et al. (2006) \\
\hline Procabacter acanthamoebae & Not described & Horn et al. (2002) \\
\hline Pseudomonas saccharophilia & Intracellular multiplication & Hoffmann and Michel (2001) \\
\hline Pseudomonas stutzeri & Intracellular multiplication & Hoffmann and Michel (2001) \\
\hline Rickettsiales & Increase in amoebae pathogenicity & Fritsche et al. (1998) \\
\hline Staphylococcus aureus & Intracellular multiplication & Huws et al. (2008) \\
\hline Salmonella enterica & Intracellular multiplication & Tezcan-Merdol et al. (2004) \\
\hline Salmonella typhimurium & Intracellular multiplication & Gaze et al. (2003) \\
\hline Simkania negevensis & Intracellular growth & Kahane et al. (2001) \\
\hline Stenotrophomonas maltophilia & Intracellular multiplication & $\begin{array}{l}\text { (Hoffmann and Michel 2001; Corsaro } \\
\text { et al. 2013) }\end{array}$ \\
\hline Streptococcus pneumoniae & Intracellular multiplication & Siddiqui et al. (2017) \\
\hline Streptococcus pyogenes & Intracellular multiplication & Siddiqui et al. (2017) \\
\hline Waddlia chondrophila & Intracellular growth & Michel et al. (2004) \\
\hline Yersinia enterocolitica & Intracellular survival & Lambrecht et al. (2013) \\
\hline
\end{tabular}


Table 1 (continued)

\begin{tabular}{lll}
\hline Organism & Changes & References \\
\hline Fungi & & \\
Candida albicans & Increase in fungal virulence & Gonçalves et al. (2019) \\
Cryptococcus neoformans & Intracellular replication, increase in fungal virulence & (Steenbergen et al. 2001; Gonçalves et al. 2019) \\
Cryptosporidium parvum & Not described & Scheid and Schwarzenberger (2011) \\
Paracoccidioides brasiliensis & Increase in fungal virulence & Gonçalves et al. (2019) \\
Sporothrix brasiliensis & Increase in fungal virulence & Gonçalves et al. (2019) \\
Virus & & \\
Adenoviruses & No multiplication observed & Scheid and Schwarzenberger (2012) \\
Coxsackieviruses & Not described & Mattana et al. (2006) \\
Marseillevirus & Not described & Boyer et al. (2009) \\
Mimivirus & Not described & Arslan et al. (2011) \\
Pandoraviruses & Not described & Philippe et al. (2013) \\
Mollivirus sibericum & Not described & Legendre et al. (2015) \\
\hline
\end{tabular}

\section{Acanthamoeba as predator}

Amoebae consume bacteria, mostly non-pathogens, as food source to fulfil their nutritional needs by taking up bacteria through phagocytosis and lysing them in phagolysosomes
(Khan and Siddiqui 2014). Due to their consumption of bacteria, amoebae play an eminent role in the regulation of bacterial density in the nature by being accountable for eradication of around $60 \%$ of the bacterial population in the environment (Rosenberg et al. 2009). Whilst both

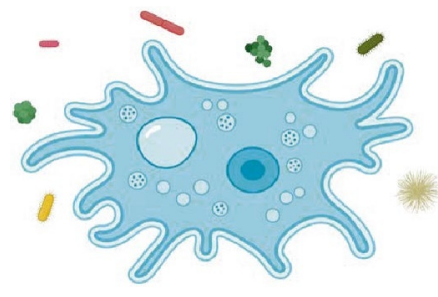

Acanthamoebae and bacteria

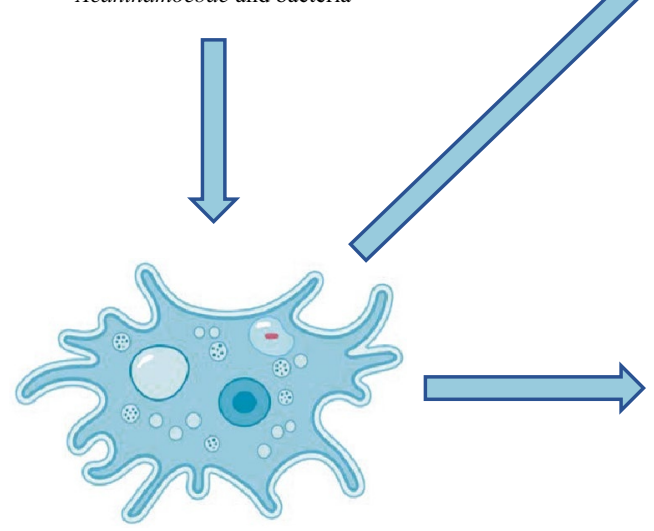

Selected bacteria invade/taken up by amoebae

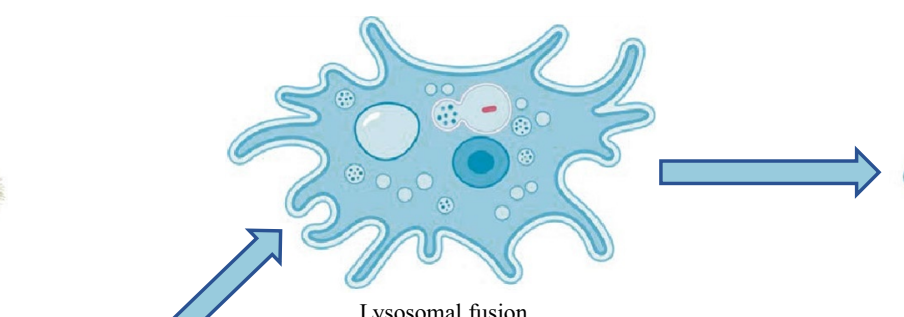

Lysosomal fusion

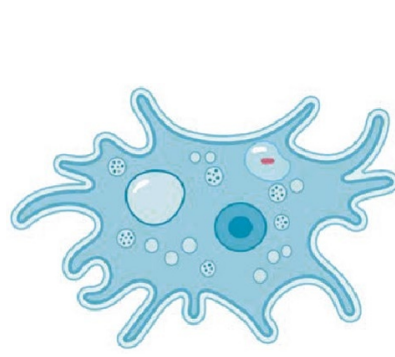

Evasion/survival of lysosomal killing

[Genetic exchanges]

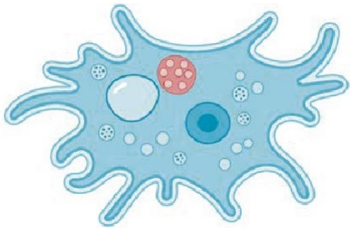

Bacteria lysed and used as food [Amoeba as predator]
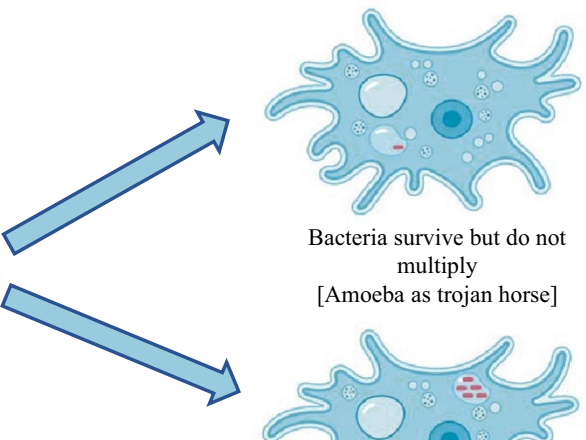

Bacteria survive but do not multiply

[Amoeba as trojan horse]

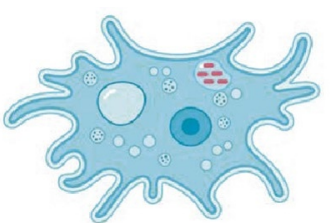

Bacteria survive and multiply [Amoeba as reservoir]
Fig. 1 Interaction of Acanthamoeba with bacteria. The figure describes how Acanthamoeba and bacteria interact, which may lead to the amoebae acting as predator, Trojan horse or reservoir. On the left-hand side, Acanthamoeba in a bacteria-rich environment following which selected bacteria are taken up by the amoeba can be observed. In the middle section, the two main options following intake of bacteria are depicted, namely, digestion or survival of the bacteria. On the right-hand side, bacteria surviving internalization into Acanthamoeba, namely, using the amoeba as a transmission vehicle or replication site, can be observed 
neuropathogenic Escherichia coli $\mathrm{K} 1$ and the non-invasive E. coli $\mathrm{K}-12$ have been shown to be present intracellularly in amoebae, K1 survived whilst K-12 were lysed by the amoebae, indicating K-12 as bacterial prey (Alsam et al. 2006). Even as a bacterial predator, it has been shown that Acanthamoeba is selective in its phagocytic uptake, since a study on the effects of Acanthamoeba on the composition of bacterial communities revealed that Betaproteobacteria and Firmicutes showed the most decrease in numbers, whilst Betaproteobacterial ammonia oxidizers and Gammaproteobacteria numbers did not change, and an increase was observed in the number of Actinobacteria, Nitrospira, Verrucomicrobia and Planctomycetes (Rosenberg et al. 2009). The selective intake of bacteria by Acanthamoeba suggests underlying mechanisms and conditions that allow selection of bacteria. As such, it has been reported that the intake of particles by Acanthamoeba is dependent on size, where latex beads of sizes between 1.035 and $2.68 \mu \mathrm{m}$ were taken up whilst bead of sizes between 0.126 to $0.557 \mu \mathrm{m}$ accumulated at the surface of the amoebae (Korn and Weisman 1967). The uptake of beads was also shown to be higher in larger cells as compared to smaller cells and was affected by the culture age and agitation of cell culture (Avery et al. 1995). Another reason for selective uptake of bacteria might be their ability to achieve high motility and escape from amoebae grazing (Jürgens and Matz 2002). It has been indicated that the amoebic vacuoles containing food are retained, and those containing non-nutrient particles are exocytosed, upon presentation of new particles, and phagocytic vesicles that are retained have been reported to fuse with each other as well as digestive vesicles (Bowers and Olszewski 1983; Wetzel and Korn 1969). It is known that surface elements, such as lipopolysaccharide, peptidoglycan, capsule and $\beta-(1-4)-N$-acetylmuramic acid, play an important role in the selection of bacteria by amoebae, and it has been reported that the phagocytosis of Acanthamoeba might be mediated by tyrosine kinase (Alsam et al. 2005, 2006; Humann and Lenz 2009). It has also been reported that actin polymerization and cytoskeletal rearrangement are processes that are involved in the phagocytotic uptake of bacteria by Acanthamoeba where killing and degradation of bacteria are caused by acidification and phagosomal-lysosomal fusion (Akya et al. 2009). Moreover, it has been noted that mannose-binding proteins and membrane-associated amoebae receptors are essential for the phagocytotic intake of bacteria by Acanthamoeba and that tyrosine kinase-induced actin polymerization, as well as PI3K and RhoA pathways, play important roles in the uptake (Medina et al. 2014). Furthermore, it was shown that the conditioned media from Acanthamoeba culture possess bactericidal activities against selected bacteria, since the medium eliminated all methicillin-resistant Staphylococcus aureus whilst showing limited effects against Acinetobacter $\mathrm{sp}$., vancomycin-resistant Enterococcus faecalis and Pseudomonas aeruginosa (Iqbal et al. 2014). Also, it was recently reported that Acanthamoeba produces a metabolite that inhibits the growth of methicillin-resistant Staphylococcus aureus (de Souza et al. 2017). Interestingly, it has been shown that Acanthamoeba may interfere with bacterial toxin production, such as 2,4-diacetylphloroglucinol and monoacetyl-phloroglucinol in Pseudomonas fluorescens (Jousset and Bonkowski 2010), which may enhance its predatorial capabilities. Interestingly, Acanthamoeba has the ability to produce protein toxins, such as the pore-forming acanthaporin, which possesses anti-bacterial activities against a variety of bacteria (Michalek et al. 2013) and hence may also promote its predatorial capabilities.

Recently, a thermodimorphic fungi, Paracoccidioides brasiliensis, was reported to be efficiently ingested, killed and digested by Acanthamoeba leading to $90 \%$ decrease in fungal colony-forming units in $24 \mathrm{~h}$, and electron microscopy revealed internalized fungal cell debris and cell wall debris inside amoeba vacuoles (Albuquerque et al. 2019). These findings indicate that the predatory characteristics of Acanthamoeba are not limited to bacteria but also affect fungi and viruses.

\section{Acanthamoeba as transmission vehicles}

Acanthamoeba can act as a "Trojan horse" for microorganisms which force their entry into amoebae, resist amoeba-mediated killing, and are hence protected by Acanthamoeba's ability to resist extreme temperatures, $\mathrm{pH}$ and osmolarity (Khan and Siddiqui 2014). The resistance of Acanthamoeba cysts to chlorine is especially beneficial to the microorganisms since elimination of intracellular microorganisms from water supplies can prove challenging (Khan 2009). Additionally, Acanthamoeba cysts are air-borne and can travel through ventilation systems/ducts, as well as long distance such as during strong winds and dust storms, that can lead to bacterial transmission to the wider community. Burkholderia cepacia and Chlamydophila pneumoniae are examples of bacteria that have been shown to use Acantham$o e b a$ as "Trojan horse", whereby they remain viable in the amoebae without growing in numbers (Khan and Siddiqui 2014). This indicates that some bacteria possess mechanisms that allow them to protect themselves from Acanthamoeba killing. As such, the Dot/Icm type IV secretion system genes encode for protein, secreted by bacteria such as Legionella, that inhibit lysosome adhesion, phagosome maturation and acidification of vesicles, protecting bacteria from attack (Molmeret et al. 2005; Taylor et al. 2009; Rubenina et al. 2017).

Fungi have been shown to interact with Acanthamoeba, and the interaction has been shown to increase the virulence of the fungi that have been shown to survive due to expression of capsular polysaccharides and melanin (Steenbergen and Casadevall 2003; Chrisman 2011; Gonçalves et al. 2019). Survival of fungi within amoebae resulted in more virulent fungi since the "surviving" fungi 
were more pathogenic when tested using in vivo models (Fuchs et al. 2010; Mylonakis 2008; Thomaz et al. 2013; Rizzo et al. 2017). Moreover, instance of fungi, namely, Cryptococcus neoformans, taken up by amoebae and then released without notable genetic or pharmacological changes have been recently reported (Watkins et al. 2018).

The cultivation of adenoviruses in the presence of Acanthamoeba was used as a model for studying their relationship, and it was revealed that Acanthamoeba is used as a carrier or a paratenic host by the virus, whereby the viruses did not proliferate or multiply inside the amoebae (Scheid and Schwarzenberger 2012). Acanthamoeba also serve as transmission vehicle for coxsackie B viruses, whereby the virus maintains its infectivity when internalized in the amoebae but does not replicate and is released during interaction between amoebae and human macrophages (Mattana et al. 2006).

In addition, the interactions of Cryptosporidium spp., a protozoan parasite that infects a wide range of vertebrate hosts, and Acanthamoeba was investigated. It was revealed that the amoebae likely act as s carriers of Cryptosporidium oocysts since the amoebae internalized several oocysts which did not show any changes in morphology (GómezCouso et al. 2007).

\section{Acanthamoeba as reservoir}

Acanthamoeba may also serve as an incubator-like reservoir for bacteria that are pathogenic to humans, where the bacteria can use the amoebae's defences to resist harsh environment and evade host defences and drugs, whilst growing in numbers inside the amoebae (Khan and Siddiqui 2014; Scheid 2014; Lim et al. 2020). Moreover, the ability of bacteria to survive in amoebae cysts has also been reported, indicating that the cysts might protect bacteria from chemical disinfection (Khan 2006; Thomas et al. 2010; Yousuf et al. 2013). In contrast to Acanthamoeba as a "Trojan horse" whereby bacteria remain viable in the amoebae without growing in numbers, when Acanthamoeba are used as reservoir, the bacteria multiply inside the amoebae. In addition to being used as a safe heaven, genetic transfer between bacteria whilst inside amoebae has been reported, indicating that the amoebae may lead to drug resistance due to transfer of genetic information related to multiple drug resistance between several bacterial species using the amoebae as a reservoir (McCuddin et al. 2006; Mella et al. 2016). Exchange of genetic material between intracellular bacteria lead to the development of virulence traits using amoebae as evolutionary crib to adapt for survival within macrophages (Harb et al. 2000; Huws et al. 2008; KebbiBeghdadi and Greub 2014). The genome of intra-amoeba microorganisms is significantly larger than that of their relatives, further confirming the role of Acanthamoeba as a gene melting pot, whilst also suggesting gene transfer from Acanthamoeba to their endosymbionts (Moliner et al. 2010). Moreover, several markers of horizontal gene transfer between genomes of intra-amoebal bacteria and between the bacterial genomes and the genomes of their amoebal hosts are additional evidence that Acanthamoeba functions as a gene melting pot (Moliner et al. 2010). One bacterium that has been extensively studied is Legionella pneumophila that has been shown to grow and multiply intracellularly of Acanthamoeba trophozoites and survive from harsh treatment, such as $50 \mathrm{mg} / \mathrm{L}$ free chlorine, inside Acanthamoeba cysts (Kilvington and Price 1990). It has also been shown that $L$. pneumophila uses the same genes to grow intracellularly in both human macrophages and amoebae since all the genes that were absolutely required for growth in human macrophages were also required for growth in Acanthamoeba (Segal and Shuman 1999). Moreover, a study comparing L. pneumophila grown in standard laboratory conditions to those grown intracellularly in Acanthamoeba revealed that bacteria grown in Acanthamoeba was 100-fold more invasive to macrophages via coiling phagocytosis at a higher frequency (Cirillo et al. 1994). Light and electron microscopy revealed differences in the structure and morphology between amoebae-grown and agar-grown L. pneumophila, and analysis of protein expression suggested that amoebagrown L. pneumophila expressed new proteins leading to phenotypic differences (Cirillo et al. 1994).

Recently, it was shown that several types of fungi can survive as well as replicate intracellularly of Acanthamoeba, indicating that Acanthamoeba also acts as a reservoir for fungi, such as Cryptococcus spp., Histoplasma capsulatum, Blastomyces dermatitides and Sporothrix schenckii (Gonçalves et al. 2019). Mannose-binding proteins have been linked to the recognition of fungi by Acanthamoeba, whereby interaction of Acanthamoeba with $H$. capsulatum, C. neoformans, Candida albicans, Saccharomyces cerevisiae and Paracoccidioides brasiliensis was inhibited by mannose (Gonçalves et al. 2019). The importance of mannose-binding protein was shown to be specific to the uptake of fungi, as mannose inhibited uptake of fungi but not latex beads (Allen and Dawidowicz 1990). It was further shown that the fungi that were taken up by Acanthamoeba were used to infect Galleria mellonella, and it was revealed that they killed the larvae faster than control yeasts in all cases (Gonçalves et al. 2019).

The first known Mimivirus, Acanthamoeba polyphaga mimivirus, was isolated from an amoebal co-culture in a water sample collected from a cooling tower of a hospital in England, following which over a dozen viruses have been identified (Abrahão et al. 2014). This virus was shown to use Acanthamoeba as a viral factory whereby viral entry and viral membrane fusion are followed by release of viral seed into amoeba cytoplasm where, within few hours, the 
viral factory grew and orchestrated the morphogenesis of the viral progeny which were subsequently released by cell lysis (Abrahão et al. 2014). Also, Faustoviruses are viruses that can use Acanthamoeba as virus factories where, $20 \mathrm{~h}$ after infection, complete viral particles are released (Reteno et al. 2015). More recently, a novel virus, Yaravirus brasiliensis, was discovered inside Acanthamoeba castellanii and was found to use the amoebae as a viral factory to create new virus following which the virus causes lysis of the amoebae (Boratto et al. 2020).

\section{Miscellaneous interactions of Acanthamoeba}

Other than Acanthamoeba acting as predator, transmission vehicles and reservoirs, other types of interactions have also been described. One such case is when Acanthamoeba internalizes Aspergillus fumigatus conidia, where part of the ingested fungi escapes the vacuole, resulting in fungal intracellular germination and subsequently causing structural changes in amoebae that causes amoebal permeabilization (Van Waeyenberghe et al. 2013). In other cases, it has been shown that fungi, such as Histoplasma capsulatum, can be phagocytosed by Acanthamoeba and convert into filamentous form, causing the death of the amoebae, whilst more virulent phenotypes of the fungi are selected or induced (Steenbergen et al. 2004).

Moreover, viruses are known to survive inside Acanthamoeba, without noticeable changes in infectivity even after 6 months, whilst the viral deoxyribonucleic acid (DNA) of numerous viruses has been detected inside the amoebae, indicating that Acanthamoeba plays a role as vector, reservoir or carrier for the viruses (Lorenzo-Morales et al. 2007; Mattana et al. 2006; Scheid and Schwarzenberger 2012). Additionally, "giant viruses" Mimiviridae were initially discovered as an intracellular endocytobiont of Acanthamoeba further indicating that there is association of great importance between Acanthamoeba and viruses ( $\mathrm{La}$ Scola et al. 2003). Later virus of the Iridoviridae family was identified as endocytobiont of Acanthamoeba and led to the discovery of new giant viruses in amoebae (Aherfi et al. 2016; Colson et al. 2012, 2013). Another group of viruses, known as Pandoraviruses, was identified from Acanthamoeba, and it was revealed that the viruses were unique, since they did not share genetic or morphological similarities to known viruses (Philippe et al. 2013; Scheid 2015, 2016; Scheid et al. 2008). There is also evidence of horizontal gene transfer between viruses and Acanthamoeba where $10 \%$ of protein encoded by the virus is homologous to Acanthamoeba protein (Legendre et al. 2015).

Interestingly, Pseudomonas chlororaphis strain PA23 is a bacterium that can produce compounds including pyrrolnitrin, phenazine and hydrogen cyanide that have been recently shown to possess both toxic and repellent effects on Acanthamoeba (Ghergab et al. 2021). Co-culture of $P$. chlororaphis and amoebae led to changes in gene expression and secondary metabolite production of bacteria, suggesting that they can sense the presence of Acanthamoeba and adjust its physiology in response (Ghergab et al. 2021).

Acanthamoeba is known to interact with bacteria, viruses as well as fungi (Mella et al. 2016). A recent study on humans with stromal keratitis has shown that Acanthamoeba infections occurred in around $10 \%$ of cases and co-infections with fungi occurred in around $5 \%$ of cases whilst co-infections with bacteria were also noted (Raghavan et al. 2019). Depending on conditions and pathogenicity of the microorganisms and the amoebae, the interactions vary leading to lysis of the microorganisms or amoebae, intake of microorganisms without any changes, incubation and growth of the microorganisms within the amoebae or increase in virulence of the microorganisms. Acanthamoeba cysts have been shown to be resistant to extreme conditions including freezing, $\mathrm{pH}$ 2.0, $\gamma$ and ultraviolet irradiation, moist heat, heavy metals, desiccation for over 20 years and storage at $4{ }^{\circ} \mathrm{C}$ for over 20 years (Sriram et al. 2008). Acanthamoeba cyst has also been shown to be resistant to biocides, chlorination and antibiotics (Marciano-Cabral and Cabral 2003). Hence, whilst acting as a reservoir or a "Trojan horse", Acanthamoebae can hence protect the endocytobionts against virtually most extreme conditions that they would encounter in the environment as well as treatments such as antibiotics and biocides. Hence, the role of Acanthamoeba as a sanctuary for pathogens and a training ground for their virulence, whilst assisting their transmission to susceptible hosts, is of huge concern to public health. As such, it has been recently suggested that amoebae might also harbour coronaviruses, responsible for COVID-19 pandemic (Siddiqui and Khan 2020a, b). The ability of Acanthamoeba to work as reservoirs or "Trojan horses" renders the connection between exposures with a pathogen, and the resulting infection more complicated as the amoebae might allow the pathogen to evade several of the host responses and defences and even allow the pathogen entry into the central nervous system of the host (Siddiqui and Khan 2020a, b). SARS-CoV-2 as an endosymbiont of Acanthamoeba might also allow it to persist in the environment, especially in the air-conditioning systems (Siddiqui and Khan 2020a). Moreover, Acanthamoeba cysts have been isolated from the brain tissue (Marciano-Cabral and Cabral 2003), indicating that some cysts might remain dormant in the host and hence may lead to recurrence of infection caused by pathogens released from the cysts. However, despite knowing that Acanthamoeba plays an essential role in the survival, evolution and transmission of a vast repertoire of microorganisms, many of which are pathogenic to humans, studies on the mechanisms behind the interaction of the amoebae with the endocytobionts 
remain scarce. Understanding the mechanisms of action involved in the uptake and release of microorganisms might allow researchers to use Acanthamoeba for the culture of obligate intracellular microorganisms that cannot be cultured in axenic media. Furthermore, if the mechanisms are revealed, it might be possible to introduce targetted antimicrobials into the amoebae to kill the endocytobionts. Recently, a study investigated the effects of Acanthamoeba in a complex microbial community in an experimental aquatic model, using 16S rRNA sequencing, and it was revealed that the amoebae did not drastically change the bacterial community but, by reducing certain oxygen-consuming bacteria, such as Cyanobacteria, affected the dissolved oxygen concentrations (Tsai et al. 2020). This indicates that due to the complex ecological processes, it is still too complex to understand the exact mechanisms of interaction between Acanthamoeba and microorganisms in a complex microbial community. Despite all the studies performed on the interaction of Acanthamoeba with microorganisms, important factors in the interactions remain unelucidated. The selection process of food by both the amoebae and the microorganisms, in other words, in the presence of Acanthamoeba, varying species of microorganisms and other food sources (such as axenic media and nutrient agar/broth) questions such as (i) what microorganisms would be taken up and protected by the amoebae, (ii) would the amoebae take up the microorganisms species by species or several species at one time, (iii) what is the mechanism behind the selection process of food source by the amoebae, (iv) what microorganisms would be used as food source by the amoebae despite the axenic media, (v) what microorganisms would force their way into the amoebae despite being in a nutritionally rich environment, (vi) what microorganisms would use the amoebae as food source despite the presence of other food sources, and (vii) what microorganisms would escape or be released from the amoebae due to the availability of nutritious environment and the mechanisms involved are areas for further investigations.

\section{Conclusion}

In general, interaction of pathogens with Acanthamoeba might cause an evolutionary pressure leading to increase in virulence, whilst, in other cases, microorganisms can be used as food source by the amoebae or the amoebae can be used as a "Trojan horse" or reservoir by the microorganisms. Understanding the molecular basis of the interactions between microorganisms and Acanthamoeba, such as receptors used by the amoeba and change in gene expressions, would give insight on how pathogenicity could be modulated and drive knowledge on the role of amoebae in diseases caused by microorganisms distributed in the environment.

Author contribution NAK and RS conceived the concept. MRM reviewed literature under the supervision of RS. MRM and RS wrote the first draft. NAK corrected and finalized the manuscript.

\section{Declarations}

Conflict of interest The authors declare no competing interests.

\section{References}

Abd H, Johansson T, Golovliov I, Sandström G, Forsman M (2003) Survival and growth of Francisella tularensis in Acanthamoeba castellanii. Appl Environ Microbiol 69(1):600-606. https://doi. org/10.1128/aem.69.1.600-606.2003

Abrahão JS, Dornas FP, Silva LC, Almeida GM, Boratto PV, Colson P, La Scola B, Kroon EG (2014) Acanthamoeba polyphaga mimivirus and other giant viruses: an open field to outstanding discoveries. Virol J 11(1):1-12. https://doi.org/10.1186/ 1743-422x-11-120

Aherfi S, Colson P, La Scola B, Raoult D (2016) Giant viruses of amoebas: an update. Front Microbiol 7:349. https://doi.org/10. 3389/fmicb.2016.00349

Akya A, Pointon A, Thomas C (2009) Mechanism involved in phagocytosis and killing of Listeria monocytogenes by Acanthamoeba polyphaga. Parasitol Res 105(5):1375. https://doi.org/10.1007/ s00436-009-1565-z

Albert-Weissenberger C, Cazalet C, Buchrieser C (2007) Legionella pneumophila - a human pathogen that co-evolved with fresh water protozoa. Cell Mol Life Sci 64(4):432. https://doi.org/10. 1007/s00018-006-6391-1

Albuquerque P, Nicola AM, Magnabosco DAG, Derengowski LDS, Crisóstomo LS, Xavier LCG, Frazão SO, Guilhelmelli F, de Oliveira MA, Dias JDN, Hurtado FA, Teixeira MM, Guimarães AJ, Paes HC, Bagagli E, Felipe MSS, Casadevall A, Silva-Pereira I (2019) A hidden battle in the dirt: soil amoebae interactions with Paracoccidioides spp. Plos Negl Trop Dis 13(10)

Allen PG, Dawidowicz EA (1990) Phagocytosis in Acanthamoeba: I. A mannose receptor is responsible for the binding and phagocytosis of yeast. J Cell Physiol 145(3):508-513. https://doi.org/10.1002/ jcp. 1041450317

Alsam S, Jeong SR, Sissons J, Dudley R, Kim KS, Khan NA (2006) Escherichia coli interactions with Acanthamoeba: a symbiosis with environmental and clinical implications. J Med Microbiol 55(6):689-694. https://doi.org/10.1099/jmm.0.46497-0

Alsam S, Sissons J, Dudley R, Khan NA (2005) Mechanisms associated with Acanthamoeba castellanii (T4) phagocytosis. Parasitol Res 96(6):402-409. https://doi.org/10.1007/s00436-005-1401-z

Arslan D, Legendre M, Seltzer V, Abergel C, Claverie JM (2011) Distant Mimivirus relative with a larger genome highlights the fundamental features of Megaviridae. Proc Natl Acad Sci USA 108(42):17486-17491. https://doi.org/10.1073/pnas.1110889108

Avery SV, Harwood JL, Lloyd D (1995) Quantification and characterization of phagocytosis in the soil amoeba Acanthamoeba castellanii by flow cytometry. Appl Environ Microbiol 61(3):11241132. https://doi.org/10.1128/aem.61.3.1124-1132.1995 
Balczun C, Scheid PL (2017) Free-living amoebae as hosts for and vectors of intracellular microorganisms with public health significance. Viruses 9(4):65. https://doi.org/10.3390/v9040065

Barker J, Humphrey TJ, Brown MW (1999) Survival of Escherichia coli 0157 in a soil protozoan: implications for disease. FEMS Microbiol Lett 173(2):291-295. https://doi.org/10.1111/j.15746968.1999.tb13516.x

Boratto PVM, Oliveira GP, Machado TB, Andrade ACSP, Baudoin JP, Klose T, Schulz F, Azza S, Decloquement P, Chabrière E, Colson P, Levasseur A, La Scola B, Abrahão JS (2020) Yaravirus: a novel 80-nm virus infecting Acanthamoeba castellanii. Proc Natl Acad Sci USA 117(28):16579-16586. https://doi.org/10.1073/ pnas. 2001637117

Bowers B, Olszewski TE (1983) Acanthamoeba discriminates internally between digestible and indigestible particles. J Cell Biol 97(2):317-322. https://doi.org/10.1083/jcb.97.2.317

Boyer M, Yutin N, Pagnier I, Barrassi L, Fournous G, Espinosa L, Robert C, Azza S, Sun S, Rossmann MG, Suzan-Monti M, La Scola B, Koonin EV, Raoult D (2009) Giant Marseillevirus highlights the role of amoebae as a melting pot in emergence of chimeric microorganisms. Proc Natl Acad Sci USA 106(51):21848-21853. https://doi.org/10.1073/pnas.0911354106

Chrisman CJ, Albuquerque P, Guimaraes AJ, Nieves E, Casadevall A (2011) Phospholipids trigger Cryptococcus neoformans capsular enlargement during interactions with amoebae and macrophages. PLoS Pathog 7(5):e1002047. https://doi.org/10.1371/journal. ppat.1002047

Cirillo JD, Falkow S, Tompkins LS (1994) Growth of Legionella pneumophila in Acanthamoeba castellanii enhances invasion. Infect Immun 62(8):3254-3261. https://doi.org/10.1128/iai.62.8.32543261.1994

Cirillo JD, Falkow S, Tompkins LS, Bermudez LE (1997) Interaction of Mycobacterium avium with environmental amoebae enhances virulence. Infect Immun 65(9):3759-3767. https://doi.org/10. 1128/iai.65.9.3759-3767.1997

Colson P, de Lamballerie X, Fournous G, Raoult D (2012) Reclassification of giant viruses composing a fourth domain of life in the new order Megavirales. Intervirology 55(5):321-332. https://doi. org/10.1159/000336562

Colson P, Pagnier I, Yoosuf N, Fournous G, La Scola B, Raoult D (2013) "Marseilleviridae", a new family of giant viruses infecting amoebae. Arch Virol 158(4):915-920. https://doi.org/10.1007/ s00705-012-1537-y

Corsaro D, Müller KD, Michel R (2013) Molecular characterization and ultrastructure of a new amoeba endoparasite belonging to the Stenotrophomonas maltophilia complex. Exp Parasitol 133(4):383-390. https://doi.org/10.1016/j.exppara.2012.12.016

de Souza TK, Soares SS, Benitez LB, Rott MB (2017) Interaction between methicillin-resistant Staphylococcus aureus (MRSA) and Acanthamoeba polyphaga. Curr Microbiol 74(5):541-549. https://doi.org/10.1007/s00284-017-1196-Z

Delafont V, Bouchon D, Héchard Y, Moulin L (2016) Environmental factors shaping cultured free-living amoebae and their associated bacterial community within drinking water network. Water Res 100:382-392. https://doi.org/10.1016/j.watres.2016.05.044

Dey R, Hoffman PS, Glomski IJ (2012) Germination and amplification of anthrax spores by soil-dwelling amoebas. Appl Environ Microbiol 78(22):8075-8081. https://doi.org/10.1128/aem. 02034-12

Drancourt M, Adékambi T, Raoult D (2007) Interactions between Mycobacterium xenopi, amoeba and human cells. J Hosp Infect 65(2):138-142. https://doi.org/10.1016/j.jhin.2006.10.006

Drozanski W (1956) Fatal bacterial infection in soil amoebae. Acta Microbiol Pol 5(3-4):315-317

Essig A, Heinemann M, Simnacher U, Marre R (1997) Infection of Acanthamoeba castellanii by Chlamydia pneumoniae. Appl
Environ Microbiol 63(4):1396-1399. https://doi.org/10.1128/ aem.63.4.1396-1399.1997

Fritsche TR, Sobek D, Gautom RK (1998) Enhancement of in vitro cytopathogenicity by Acanthamoeba spp. following acquisition of bacterial endosymbionts. FEMS Microbiol Lett 166(2):231-236. https://doi.org/10.1111/j.1574-6968.1998. tb13895.x

Fuchs BB, O’Brien E, Khoury JB, Mylonakis E (2010) Methods for using Galleria mellonella as a model host to study fungal pathogenesis. Virulence 1(6):475-482. https://doi.org/10.4161/viru.1. 6.12985

Gaze WH, Burroughs N, Gallagher MP, Wellington EM (2003) Interactions between Salmonella typhimurium and Acanthamoeba polyphaga, and observation of a new mode of intracellular growth within contractile vacuoles. Microb Ecol 46(3):358-369. https:// doi.org/10.1007/s00248-003-1001-3

Ghergab A, Selin C, Tanner J, Brassinga AK, Dekievit T (2021) Pseudomonas chlororaphis PA23 metabolites protect against protozoan grazing by the predator Acanthamoeba castellanii. PeerJ 9:e10756. https://doi.org/10.7717/peerj.10756

Gómez-Couso H, Paniagua-Crespo E, Ares-Mazás E (2007) Acanthamoeba as a temporal vehicle of Cryptosporidium. Parasitol Res 100(5):1151-1154. https://doi.org/10.1007/s00436-006-0377-7

Gonçalves DS, Ferreira MDS, Gomes KX, Rodríguez-de La Noval C, Liedke SC, da Costa GCV, Albuquerque P, Cortines JR, Saramago Peralta RH, Peralta JM, Casadevall A, Guimarães AJ (2019) Unravelling the interactions of the environmental host Acanthamoeba castellanii with fungi through the recognition by mannose-binding proteins. Cell Microbiol 21(10):e13066. https://doi.org/10.1111/cmi.13066

Greub G, Raoult D (2004) Microorganisms resistant to free-living amoebae. Clin Microbiol Rev 17(2):413-433. https://doi.org/ 10.1128/cmr.17.2.413-433.2004

Grillot-Courvalin C, Goussard S, Huetz F, Ojcius DM, Courvalin P (1998) Functional gene transfer from intracellular bacteria to mammalian cells. Nat Biotechnol 16(9):862-866. https://doi.org/ 10.1038/nbt0998-862

Harb OS, Gao LY, Abu Kwaik Y (2000) From protozoa to mammalian cells: a new paradigm in the life cycle of intracellular bacterial pathogens: Minireview. Environ Microbiol 2(3):251-265. https:// doi.org/10.1046/j.1462-2920.2000.00112.x

Hoffmann R, Michel R (2001) Distribution of free-living amoebae (FLA) during preparation and supply of drinking water. Int $\mathrm{J}$ Hyg Environ Health 203(3):215-219. https://doi.org/10.1078/ s1438-4639(04)70031-0

Horn M, Fritsche TR, Gautom RK, Schleifer KH, Wagner M (1999) Novel bacterial endosymbionts of Acanthamoeba spp. related to the Paramecium caudatum symbiont Caedibacter caryophilus. Environ Microbiol 1(4):357-367. https://doi.org/10.1046/j. 1462-2920.1999.00045.x

Horn M, Fritsche TR, Linner T, Gautom RK, Harzenetter MD, Wagner M (2002) Obligate bacterial endosymbionts of Acanthamoeba spp. related to the beta-Proteobacteria: proposal of 'Candidatus Procabacter acanthamoebae' gen. nov., sp. nov. Int J Syst Evol Microbiol 52(2):599-605. https://doi.org/10.1099/00207713-52-2-599

Horn M, Harzenetter MD, Linner T, Schmid EN, Müller KD, Michel R, Wagner M (2001) Members of the Cytophaga-FlavobacteriumBacteroides phylum as intracellular bacteria of acanthamoebae: proposal of 'Candidatus Amoebophilus asiaticus'. Environ Microbiol 3(7):440-449. https://doi.org/10.1046/j.1462-2920. 2001.00210.x

Humann J, Lenz LL (2009) Bacterial peptidoglycan-degrading enzymes and their impact on host muropeptide detection. J Innate Immun 1(2):88-97. https://doi.org/10.1159/000181181

Huws SA, Morley RJ, Jones MV, Brown MR, Smith AW (2008) Interactions of some common pathogenic bacteria with Acan- 
thamoeba polyphaga. FEMS Microbiol Lett 282(2):258-265. https://doi.org/10.1111/j.1574-6968.2008.01123.x

Iqbal J, Siddiqui R, Khan NA (2014) Acanthamoeba and bacteria produce antimicrobials to target their counterpart. Parasit Vectors 7(1):56. https://doi.org/10.1186/1756-3305-7-56

Jousset A, Bonkowski M (2010) The model predator Acanthamoeba castellanii induces the production of 2, 4, DAPG by the biocontrol strain Pseudomonas fluorescens Q2-87. Soil Biol Biochem 42(9):1647-1649. https://doi.org/10.1016/j.soilbio. 2010.05.018

Jürgens K, Matz C (2002) Predation as a shaping force for the phenotypic and genotypic composition of planktonic bacteria. Antonie Van Leeuwenhoek 81(1-4):413-434. https://doi.org/10.1023/a: 1020505204959

Kahane S, Dvoskin B, Mathias M, Friedman MG (2001) Infection of Acanthamoeba polyphaga with Simkania negevensis and $S$. negevensis Survival within Amoebal Cysts. Appl Environ Microbiol 67(10):4789-4795. https://doi.org/10.1128/aem.67.10.47894795.2001

Kebbi-Beghdadi C, Greub G (2014) Importance of amoebae as a tool to isolate amoeba-resisting microorganisms and for their ecology and evolution: the Chlamydia paradigm. Environ Microbiol Rep 6(4):309-324. https://doi.org/10.1111/1758-2229.12155

Khan NA (2006) Acanthamoeba: biology and increasing importance in human health. FEMS Microbiol Rev 30(4):564-595. https:// doi.org/10.1111/j.1574-6976.2006.00023.x

Khan NA (2009) Acanthamoeba: biology and pathogenesis. Caister Academic Press. 424. ISBN 978-1-904455-43-1

Khan NA, Siddiqui R (2014) Predator vs aliens: bacteria interactions with Acanthamoeba. Parasitology 141(7):869-874. https://doi. org/10.1017/s003118201300231x

Kilvington S, Price J (1990) Survival of Legionella pneumophila within cysts of Acanthamoeba polyphaga following chlorine exposure. J Appl Bacteriol 68(5):519-525. https://doi.org/10. 1111/j.1365-2672.1990.tb02904.x

King CH, Shotts EB Jr, Wooley RE, Porter KG (1988) Survival of coliforms and bacterial pathogens within protozoa during chlorination. Appl Environ Microbiol 54(12):3023-3033. https://doi. org/10.1128/aem.54.12.3023-3033.1988

Korn ED, Weisman RA (1967) Phagocytosis of latex beads by Acanthamoeba: II. Electron Microscopic Study of the Initial Events. J Cell Biol 34(1):219-227. https://doi.org/10.1083/jcb.34.1.219

Kuburich NA, Adhikari N, Hadwiger JA (2016) Acanthamoeba and Dictyostelium use different foraging strategies. Protist 167(6):511-525. https://doi.org/10.1016/j.protis.2016.08.006

La Scola B, Audic S, Robert C, Jungang L, de Lamballerie X, Drancourt M, Birtles R, Claverie JM, Raoult D (2003) A giant virus in amoebae. Science 299(5615):2033-2033. https://doi.org/ $10.1126 /$ science. 1081867

La Scola B, Raoult D (2001) Survival of Coxiella burnetii within freeliving amoeba Acanthamoeba castellanii. Clin Microbiol Infect 7(2):75-79. https://doi.org/10.1046/j.1469-0691.2001.00193.x

Lambrecht E, Baré J, Van Damme I, Bert W, Sabbe K, Houf K (2013) Behavior of Yersinia enterocolitica in the presence of the bacterivorous Acanthamoeba castellanii. Appl Environ Microbiol 79(20):6407-6413. https://doi.org/10.1128/aem.01915-13

Landers P, Kerr KG, Rowbotham TJ, Tipper JL, Keig PM, Ingham E, Denton M (2000) Survival and growth of Burkholderia cepacia within the free-living amoeba Acanthamoeba polyphaga. Eur J Clin Microbiol Infect Dis 19(2):121-123. https://doi.org/10. 1007/s100960050442

Legendre M, Lartigue A, Bertaux L, Jeudy S, Bartoli J, Lescot M, Alempic JM, Ramus C, Bruley C, Labadie K, Shmakova L, Rivkina E, Couté Y, Abergel C, Claverie JM (2015) In-depth study of Mollivirus sibericum, a new 30,000-y-old giant virus infecting
Acanthamoeba. Proc Natl Acad Sci USA 112(38):E5327-E5335. https://doi.org/10.1073/pnas.1510795112

Lim WG, Tong T, Chew J (2020) Chryseobacterium indologenes and Chryseobacterium gleum interact and multiply intracellularly in Acanthamoeba castellanii. Exp Parasitol 211:107862. https://doi. org/10.1016/j.exppara.2020.107862

Lorenzo-Morales J, Coronado-Alvarez N, Martínez-Carretero E, Maciver SK, Valladares B (2007) Detection of four adenovirus serotypes within water-isolated strains of Acanthamoeba in the Canary Islands. Spain Am J Trop Med Hyg 77(4):753-756

Ly TM, Müller HE (1990) Ingested Listeria monocytogenes survive and multiply in protozoa. J Med Microbiol 33(1):51-54. https:// doi.org/10.1099/00222615-33-1-51

Marciano-Cabral F, Cabral G (2003) Acanthamoeba spp. as agents of disease in humans. Clin Microbiol Rev 16(2):273-307. https:// doi.org/10.1128/cmr.16.2.273-307.2003

Mattana A, Serra C, Mariotti E, Delogu G, Fiori PL, Cappuccinelli $P$ (2006) Acanthamoeba castellanii promotion of in vitro survival and transmission of coxsackie b3 viruses. Eukaryot Cell 5(4):665-671. https://doi.org/10.1128/ec.5.4.665-671.2006

McCuddin ZP, Carlson SA, Rasmussen MA, Franklin SK (2006) Klebsiella to Salmonella gene transfer within rumen protozoa: implications for antibiotic resistance and rumen defaunation. Vet Microbiol 114(3-4):275-284. https://doi.org/10.1016/j.vetmic. 2005.12.004

Medina G, Flores-Martin S, Fonseca B, Otth C, Fernandez H (2014) Mechanisms associated with phagocytosis of Arcobacter butzleri by Acanthamoeba castellanii. Parasitol Res 113(5):1933-1942. https://doi.org/10.1007/s00436-014-3842-8

Mella C, Medina G, Flores-Martin S, Toledo Z, Simaluiza RJ, PérezPérez G, Fernández H (2016) Interaction between zoonotic bacteria and free living amoebas. A new angle of an epidemiological polyhedron of public health importance?. Austral J Vet Sci 48(1):1-10

Michalek M, Sönnichsen FD, Wechselberger R, Dingley AJ, Hung CW, Kopp A, Wienk H, Simanski M, Herbst R, Lorenzen I, MarcianoCabral F, Gelhaus C, Gutsmann T, Tholey A, Grötzinger J, Leippe M (2013) Structure and function of a unique poreforming protein from a pathogenic Acanthamoeba. Nat Chem Biol 9(1):37-42. https://doi.org/10.1038/nchembio.1116

Michel R, Hauröder B (1997) Isolation of an Acanthamoeba strain with intracellular Burkholderia pickettii infection. Zentralbl Bakteriol 285(4):541-557. https://doi.org/10.1016/s0934-8840(97)80116-8

Michel R, Müller KD, Amann R, Schmid EN (1997) Legionella-like slender rods multiplying within a strain of Acanthamoeba sp. isolated from drinking water. Parasitol Res 84(1):84-88. https:// doi.org/10.1007/s004360050362

Michel R, Steinert M, Zoeller L, Hauroeder B, Henning K (2004) Free-living amoebae may serve as hosts for the Chlamydia-like bacterium Waddlia chondrophila isolated from an aborted bovine foetus. Acta Protozool 43(1):37-42

Moliner C, Fournier PE, Raoult D (2010) Genome analysis of microorganisms living in amoebae reveals a melting pot of evolution. FEMS Microbiol Rev 34(3):281-294. https://doi.org/10.1111/j. 1574-6976.2010.00209.x

Molmeret M, Horn M, Wagner M, Santic M, Abu Kwaik Y (2005) Amoebae as training grounds for intracellular bacterial pathogens. Appl Environ Microbiol 71(1):20-28. https://doi.org/10. 1128/aem.71.1.20-28.2005

Moreira D, Brochier-Armanet C (2008) Giant viruses, giant chimeras: the multiple evolutionary histories of Mimivirus genes. BMC Evol Biol 8(1):12. https://doi.org/10.1186/1471-2148-8-12

Moreno-Mesonero L, Moreno Y, Alonso JL, Ferrús MA (2016) DVCFISH and PMA-qPCR techniques to assess the survival of Helicobacter pylori inside Acanthamoeba castellanii. Res Microbiol 167(1):29-34. https://doi.org/10.1016/j.resmic.2015.08.002 
Mylonakis E (2008) Galleria mellonella and the study of fungal pathogenesis: making the case for another genetically tractable model host. Mycopathologia 165(1):1-3. https://doi.org/ 10.1007/s11046-007-9082-z

Philippe N, Legendre M, Doutre G, Couté Y, Poirot O, Lescot M, Arslan D, Seltzer V, Bertaux L, Bruley C, Garin J, Claverie JM, Abergel C (2013) Pandoraviruses: amoeba viruses with genomes up to $2.5 \mathrm{Mb}$ reaching that of parasitic eukaryotes. Science 341(6143):281-286. https://doi.org/10.1126/ science. 1239181

Prasad BK, Gupta SK (1978) Preliminary report on the engagement and retention of Mycobacteria by trophozoites of exenically grown Acanthamoeba castellanii douglas. Curr Sci 47(7):245-247

Proca-Ciobanu M, Lupascu GH, Al P, Ionescu MD (1975) Electron microscopic study of a pathogenic Acanthamoeba castellani strain: the presence of bacterial endosymbionts. Int J Parasitol 5(1):49-56. https://doi.org/10.1016/0020-7519(75)90097-1

Raghavan A, Baidwal S, Venkatapathy N, Rammohan R (2019) The Acanthamoeba-Fungal Keratitis Study. Am J Ophthalmol 201:31-36. https://doi.org/10.1016/j.ajo.2019.01.024

Reteno DG, Benamar S, Khalil JB, Andreani J, Armstrong N, Klose T, Rossmann M, Colson P, Raoult D, La Scola B (2015) Faustovirus, an asfarvirus-related new lineage of giant viruses infecting amoebae. J Virol 89(13):6585-6594. https://doi.org/ 10.1128/jvi.00115-15

Rizzo J, Albuquerque PC, Wolf JM, Nascimento R, Pereira MD, Nosanchuk JD, Rodrigues ML (2017) Analysis of multiple components involved in the interaction between Cryptococcus neoformans and Acanthamoeba castellanii. Fungal Biol 121(6-7):602-614. https://doi.org/10.1016/j.funbio.2017.04. 002

Rosenberg K, Bertaux J, Krome K, Hartmann A, Scheu S, Bonkowski M (2009) Soil amoebae rapidly change bacterial community composition in the rhizosphere of Arabidopsis thaliana. The ISME J 3(6):675-684. https://doi.org/10.1038/ismej.2009.11

Rowbotham TJ (1980) Preliminary report on the pathogenicity of Legionella pneumophila for freshwater and soil amoebae. J Clin Pathol 33(12):1179-1183. https://doi.org/10.1136/jcp.33.12. 1179

Rubeniṇa I, Kirjušina M, Bērziṇš A, Valciṇa O, Jahundoviča I (2017) Relationships between free-living amoeba and their intracellular bacteria. In Proceedings of the Latvian Academy of Sciences. Section B. Natural, Exact, and Applied Sciences, 71(4):259-265. https://doi.org/10.1515/prolas-2017-0044

Scheid P, Zöller L, Pressmar S, Richard G, Michel R (2008) An extraordinary endocytobiont in Acanthamoeba sp. isolated from a patient with keratitis. Parasitol Res 102(5):945-950. https:// doi.org/10.1007/s00436-007-0858-3

Scheid PL (2014) Relevance of free-living amoebae as hosts for phylogenetically diverse microorganisms. Parasitol Res 113(7):24072414. https://doi.org/10.1007/s00436-014-3932-7

Scheid PL (2015) Viruses in close associations with free-living amoebae. Parasitol Res 114(11):3959-3967. https://doi.org/10.1007/ s00436-015-4731-5

Scheid PL (2016) A strange endocytobiont revealed as largest virus. Curr Opin Microbiol 31:58-62. https://doi.org/10.1016/j.mib. 2016.02.005

Scheid PL, Schwarzenberger R (2011) Free-living amoebae as vectors of cryptosporidia. Parasitol Res 109(2):499-504. https://doi.org/ 10.1007/s00436-011-2287-6

Scheid PL, Schwarzenberger R (2012) Acanthamoeba spp. as vehicle and reservoir of adenoviruses. Parasitol Res 111(1):479-485. https://doi.org/10.1007/s00436-012-2828-7

Segal G, Shuman HA (1999) Legionella pneumophila utilizes the same genes to multiply within Acanthamoeba castellanii and human macrophages. Infect Immun 67(5):2117-2124. https://doi.org/ 10.1128/iai.67.5.2117-2124.1999

Siddiqui R, Khan NA (2012) War of the microbial worlds: who is the beneficiary in Acanthamoeba-bacterial interactions? Exp Parasitol 130(4):311-313. https://doi.org/10.1016/j.exppara.2012. 01.021

Siddiqui R, Khan NA (2020a) War on terror cells: strategies to eradicate "novel coronavirus" effectively. ACS Chem Neurosci 11(9):11981199. https://doi.org/10.1021/acschemneuro.0c00162

Siddiqui R, Khan NA (2020b) Centralized air-conditioning and transmission of novel coronavirus. Pathog Glob Health 114(5):228229. https://doi.org/10.1080/20477724.2020.1765653

Siddiqui R, Yee Ong TY, Jung SY, Khan NA (2017) Acanthamoeba castellanii interactions with Streptococcus pneumoniae and Streptococcus pyogenes. Exp Parasitol 183:128-132. https:// doi.org/10.1016/j.exppara.2017.08.005

Snelling WJ, McKenna JP, Lecky DM, Dooley JS (2005) Survival of Campylobacter jejuni in waterborne protozoa. Appl Environ Microbiol 71(9):5560-5571. https://doi.org/10.1128/aem.71.9. 5560-5571.2005

Sriram R, Shoff M, Booton G, Fuerst P, Visvesvara GS (2008) Survival of Acanthamoeba cysts after desiccation for more than 20 years. J Clin Microbiol 46(12):4045-4048. https://doi.org/10.1128/jcm. 01903-08

Steenbergen JN, Casadevall A (2003) The origin and maintenance of virulence for the human pathogenic fungus Cryptococcus neoformans. Microbes Infect 5(7):667-675. https://doi.org/10.1016/ s1286-4579(03)00092-3

Steenbergen JN, Nosanchuk JD, Malliaris SD, Casadevall A (2004) Interaction of Blastomyces dermatitidis, Sporothrix schenckii, and Histoplasma capsulatum with Acanthamoeba castellanii. Infect Immun 72(6):3478-3488. https://doi.org/10.1128/iai.72.6. 3478-3488.2004

Steenbergen JN, Shuman HA, Casadevall A (2001) Cryptococcus neoformans interactions with amoebae suggest an explanation for its virulence and intracellular pathogenic strategy in macrophages. Proc Natl Acad Sci USA 98(26):15245-15250. https://doi.org/ 10.1073/pnas.261418798

Taylor M, Ross K, Bentham R (2009) Legionella, protozoa, and biofilms: interactions within complex microbial systems. Microb Ecol 58(3):538-47. https://doi.org/10.1007/s00248-009-9514-z

Tezcan-Merdol D, Ljungström M, Winiecka-Krusnell J, Linder E, Engstrand L, Rhen M (2004) Uptake and replication of Salmonella enterica in Acanthamoeba rhysodes. Appl Environ Microbiol 70(6):3706-3714. https://doi.org/10.1128/aem.70.6. 3706-3714.2004

Thomas V, Herrera-Rimann K, Blanc DS, Greub G (2006) Biodiversity of amoebae and amoeba-resisting bacteria in a hospital water network. Appl Environ Microbiol 72(4):2428-2438. https://doi. org/10.1128/aem.72.4.2428-2438.2006

Thomas V, McDonnell G, Denyer SP, Maillard JY (2010) Free-living amoebae and their intracellular pathogenic microorganisms: risks for water quality. FEMS Microbiol Rev 34(3):231-259. https:// doi.org/10.1111/j.1574-6976.2009.00190.x

Thomaz L, García-Rodas R, Guimarães AJ, Taborda CP, Zaragoza O, Nosanchuk JD (2013) Galleria mellonella as a model host to study Paracoccidioides lutzii and Histoplasma capsulatum. Virulence 4(2):139-146. https://doi.org/10.4161/viru.23047

Tomov AT, Tsvetkova ED, Tomova IA, Michailova LI, Kassovski VK (1999) Persistence and multiplication of obligate anaerobe bacteria in amebae under aerobic conditions. Anaerobe 5(1):19-23. https://doi.org/10.1006/anae.1999.0182

Tsai CM, Chen JW, Lin WC (2020) Effects of Acanthamoeba castellanii on the dissolved oxygen and the microbial community under the experimental aquatic model. Exp Parasitol 218:107985. https://doi.org/10.1016/j.exppara.2020.107985 
Van Waeyenberghe L, Baré J, Pasmans F, Claeys M, Bert W, Haesebrouck F, Houf K, Martel A (2013) Interaction of Aspergillus fumigatus conidia with Acanthamoeba castellanii parallels macrophage-fungus interactions. Environ Microbiol Rep 5(6):819-824. https://doi.org/10.1111/1758-2229.12082

Wagner Y, Noack B, Hoffmann T, Jacobs E, Lück CP (2006) Periodontopathogenic bacteria multiply in the environmental amoeba Acanthamoeba castellani. Int J Hyg Environ Health 209(6):535539. https://doi.org/10.1016/j.ijheh.2006.05.006

Watkins RA, Andrews A, Wynn C, Barisch C, King JS, Johnston SA (2018) Cryptococcus neoformans escape from Dictyostelium amoeba by both WASH-mediated constitutive exocytosis and vomocytosis. Front Cell Infect Microbiol 8:108. https://doi.org/ 10.3389/fcimb.2018.00108

Wetzel MG, Korn ED (1969) Phagocytosis of latex beads by Acanthamoeba castellanii (Neff) III. Isolation of the phagocytic vesicles and their membranes. J Cell Biol 43(1):90-104. https://doi. org/10.1083/jcb.43.1.90
Winiecka-Krusnell J, Wreiber K, von Euler A, Engstrand L, Linder E (2002) Free-living amoebae promote growth and survival of Helicobacter pylori. Scand J Infect Dis 34(4):253-256. https:// doi.org/10.1080/00365540110080052

Yousuf FA, Siddiqui R, Khan NA (2013) Acanthamoeba castellanii of the T4 genotype is a potential environmental host for Enterobacter aerogenes and Aeromonas hydrophila. Parasit Vectors 6(1):169. https://doi.org/10.1186/1756-3305-6-169

Zhang J, Ormälä-Odegrip AM, Mappes J, Laakso J (2014) Top-down effects of a lytic bacteriophage and protozoa on bacteria in aqueous and biofilm phases. Ecol Evol 4(23):4444-4453. https://doi. org/10.1002/ece3.1302

Publisher's Note Springer Nature remains neutral with regard to jurisdictional claims in published maps and institutional affiliations. 